\title{
Navigating Gendered Space with Special Reference to Lil Bahadur Chettri's Mountains Painted with Turmeric
}

\author{
Dr. Tamishra Swain and Ms. Shalini Shah
}

\begin{abstract}
It is rightly put by the French philosopher Simone De Beauvoir in her book 'Second Sex' that "one is not born but made a woman". So, women are treated secondary as compared to men for a long time. Similar view has been propounded by Judith Butler in her book 'Gender Trouble' that female identity has been created by repetitive performances and further, gender identity is not fixed rather it is created. There are certain agencies through which these ideologies came in to function. One of such agencies is "space" which is not necessarily physical and fixed but can be mental/psychological and fluid. This space can also use as subversive technique to control certain part of the society. This paper tries to analyze a Nepali fiction 'Mountains Painted with Turmeric' by Lil Bahadur Chetttri to understand the subversive practices of space and how it controls gender identity.
\end{abstract}

\section{Introduction}

In postmodern age the concept of space came into the forefront challenging the importance of time in narratology, which was always given more importance than geographical space. Fredric Jameson has the opinion that, "our daily life, 
our psychic experiences, our cultural languages are dominated by categories of space rather than by categories of time" (Jameson, 1991). Space, hence, has moved into the foreground of critical discussion these days. Earlier chronological narration was important, now the space where any particular event happened too is equally given importance. Postmodernist thinkers strongly opined that space is created socially by power structure and knowledge. They are of the opinion that space is never neutral but always discursively constructed, and shaped by the dominant power structures. In other words, the manifestation of space is both created and expressed through cultural discourse, so, in this case of gender discourse, fixed gender role is culturally disseminated and internalize from generation to generation. This paper tries to analyse the gender construction within the dialectics of space and time existing in Lil Bahadur Chettri's Mountains Painted with Turmeric by making use of theories given by Henri Lefebvre, Michael Foucault and Edward Soja.

\section{Lil Bahadur Chettri: A Brief Biography}

Lil Bahadur Chettri is a Nepali writer, recipient of Sahitya Academy Award for his book Brahmaputra ko Cheu Chau. His other book Basain is included in the curriculum of Tribhuvan University, Nepal. Lil Bahadur Chettri was originally from Nepal but settled in India later on. He was born in 1923 and a migrant himself, he understands the pain and plight of migrants who were uprooted from their own country and doesn't belong to the new country as well. He is considered as one of the most successful and popular novelist of Nepali language as he minutely observes the people and 
condition and portrays them realistically as well. Chettri has sensitive eyes who could see the sufferings of marginalised and narrated the experiences vividly which can touch the human emotion and through this, he sensitizes and force the readers to think ethically. Though Chettri not only narrats about the darker sides of feudalism but also talks about the patriarchy that denies the women their basic rights.

\section{Summary of the Novel}

The novel Mountains painted in Turmeric is set in the hills of far-eastern Nepal. It depicts the natural beauty, scenes from villages, life of village peasants and agricultural cycle along with the socio-cultural life style of the village peasants. The main character Dhane Basnet, is a farmer and stays in village with his wife Maina, sister Jhuma and a two- year old son. However, the life of a peasant is never easy; it has its own struggles and sufferings for existence. Dhane's happy life too is shattered when a tragedy falls into his family. The narration begins with the problem of Dhane who buys a buffalo hoping to feed his son with milk and earn some money. However, as ill luck would have it his buffalo dies and he is unable to repay the debt to moneylender. As observed by Hutt, "Chettri portrays the Dukha or suffering and sorrow, endured by ordinary peasants; the exploitation of the poor by the rich and powerful and the social conservatism that twists a community into punishing a woman for being the victim of a crime. Chettri also describes the impoverishment dispossession and banishment of Dhane's family to expose profound divisions between those who prosper and those who are slowly stripped of their meager possessions." (2008, Cover page). 
Simultaneously, there is another narration with Jhuma who meets a soldier, a migrant from the neighbouring village and gradually she falls in love with him. They share a very close relationship which was not liked by Karki, another boy from the village who likes Jhuma very much and always tries to save Jhuma from any kind of trouble. Unfortunately, Jhuma an innocent village girl could not understand the ill motive behind the soldier and falls into his trap. Though Karki tries to help Jhuma and his brother but failes to do so. With lots of monetary burden Dhane loses his livestock, his field and house to repay the loan. In the meantime Jhuma too wis ditched by the soldier who leaves impregnating her. Discovering this Jhuma goes to commit suicide but is ultimately saved by Karki who not only offers her shelter but also proposes her to marry him. The novel ends with Dhane leaving his village with the family hoping for a better future somewhere else. In this sense the writer, Lil Bahadur Chettri provides a voice to the subaltern voiceless.

\section{Theorizing Space: with Special Reference to Postmodernism}

The postmodern concept of space challenges the Cartesian dialectics; space as physical, static and fixed, rather it supports Foucauldian notion of space as fluid, multidimensional and always in flux. Space is not necessarily a geographical entity rather it can be mental/psychological. However, may it be physical or psychological, space is never innocent as it is always replete with human desire and aspiration, and hence it is always controlled by certain ideologies. As rightly said by Gramsci to create "hegemony" 
one needs to naturalize certain dominating ideologies and this is true in case of Indian patriarchal society where women are negotiating every day to sustain themselves in a male dominated culture. In Postmodern era specifically, since 1960s scholars started questioning the space. Any understanding between human agency and social structure necessarily involves space and hence, space is never innocent as it is always replete with human desire aspiration etc. and above all it marginalizes certain groups. As aptly conveyed by Rose "No space is free from human intent, desire or imagination." (1996). Foucault once said 'a whole history remains to be written of spaces '(quoted in Gordon 1980:149). Space is a value filled entity. Hence, space becomes a passive locus/container for social action, events and processes, the 'unchanging backdrop against which life is played out' (Lefebvre 1991, quoted in Mitchell 2000: 215). Additionally, Edward Soja, the writer of Third Space said, "space has to be increasingly perceived as humanly constitute and socially produced" (Soja, 1989).

Space can have multiple connotation/meanings. Similarly, at times female body too acts as space which is always controlled by men's ideology. Women always try to claim a space for themselves where they can enjoy the liberty, freedom and can have their own identity. However, seeking a space in society especially patriarchal society is not easy as space is normally gendered, of course gendered space is not natural but socially constructed. For example, private and public spaces are normally accepted as female and male space respectively. Women must occupy the private space, for example, look after one's family and household things and men will go out to manage outside business especially they 
have the responsibility to earn money working outside. Though this segregation is not natural but man-made provisions, but it is preached and practiced for years in such a way that it has become a natural phenomenon. Saraswati Raju is of the opinion that "most of the activity spaces, inside/outside, private/public, home/markets, etc., are neither simple sexually segregated geographical locations nor are they mutually exclusive- the binaries are interchangeable and in constant flux and yet across cultures, these spaces are replete with meanings connoting a hierarchical order of power in which women get associated with inside, private and home... " (Introduction, 1).

The superior position of man is prominently visible in the text and at the same time the concept of outside or public space is aptly discussed by the writer. The male characters may it be Dhane or the soldier or the landlord or Karki, all of them are involved in public space and important decisions are made by them as well. So, mostly women are restricted to an enclosed space of house and normally do not have access to public space and especially that space which is highly valued in any society for example space for education which a woman is deprived of for since a long time. So, they hardly contribute anything to the decision making process.

\section{Female Body as Physical and Mental Space}

As already mentioned space is not necessarily geographical space, but sometimes it is psychological and yet at another level it is a physical body. Women's body too is considered as space as she has to act according to the moral values set by 
patriarchy even though the physical space is divided into private and public space and private space is meant for female while public space is meant for male but the decision what to do and how to do is decided by male. The Physical movement of the woman is always supervised and controlled by the male. Body is always perceived as sexual object by men. Men control the women sometimes by coercive majors and exploit her body. Rape is one of the ways to suppress and subjugate woman. The popular Indian myth of Ramayan too has the similar evidence. When Surpanakha expressed her love for Ram her nose and ears were chopped off by Laxman and her body was disfigured just to make her helpless and docile because women's expression of self is never tolerated in a patriarchal society. Similarly, Jhuma's aspiration for freedom is never encouraged.

Physical space is also created socially and thus behaviour, household chores, family hierarchy become utmost importance. Men/women are divided into inside /outside binaries. Here, the concept of threshold comes into existence. Many myths and stories are associated with it. One of the myths/symbol which is much discussed and popular is Laxman Rekha. In jungle before leaving Sita alone Laxman drew three rekhas /straight lines and instructed Sita not to go beyond that. However, when Ravan came as a disguise of a hermit she crossed the three lines to give him alms and she was abducted by Ravan. She faced terrible problems after that. This myth is used to teach women the inside/outside binaries. If a lady crosses the limit of Laxman Rekha she has to suffer. It denotes a strong sense of that which is 'inside' and that which is 'out there'. The similar thing we observe in Jhuma and Maina's case. Jhuma tries to go beyond the 
Laxman Rekha by befriending with and dating a soldier and as a result calamities befall upon her. This is what Maina shouted at her when she came to know about the plight of Jhuma. As rightly said by Gramsci "hegemony" is created through ideology and that ideology was made naturalized by certain ways where people imbibe those things as natural and act according to that. In this case Maina too believes that Jhuma transgressed the boundaries meant for women and thus faced all the sufferings.

"Unable to restrain herself, Maina went outside and began to hurl abuse at Jhuma...Then the friends who once embraced her would abhor her. Voices would surround her, saying "Sinner! Sinner!" (2008, p.79). However, in this inside/outside boundary the concept of threshold became the utmost importance. It is a real as well as a symbolic bar marking a critical transition. "Men have, traditionally; passed over the threshold unchallenged and partaken of both worlds where as women have been expected to inhabit only the one world contained by the boundaries of home. For women, a step over the bar is an act of transgression. Having committed that act, they may never re-enter their designated first world making the other world their permanent space. And alien to the previous world. The law therefore allows multiple existences for men, a single for women." (Lal, 12). As is evident in the case of Jhuma, sister of Dhane. Threshold as dichotomies will be there and she has to decide whether to remain inside or go outside to find her freedom and identity. But once she discovers that she is pregnant she goes to commit suicide and is saved by Karki. Istead of coming back home they decide to create their own home somewhere else, as they strongly believe that Jhuma would never be accepted by neither the 
villagers or by the family members. Thus, they leave the village for good along with it the hegemonic social order where tradition, custom, rituals were important than the life of a human being. The space outside is thus a male domain which Jhuma is unable to negotiate and she has no other alternative but to submit to the male dominance.

In her book, Living the Body: Embodiment, Womanhood and Identity in Contemporary India, Meenkashi Thapan contends that, "We are embodied socially through our location in a socio-cultural and political space. In this sense, we are located in time and space, race, ethnicity and gender, and history and culture which shape and limit us in different. Our embodiment is therefore experienced in our everyday lives as lived and communicative bodies....we use our bodily senses to both perceive and give voice to our experience" (2-3).

The female bodies in action in the given Mountain painted with Turmeric are not only reified spaces where men execute their violence and control but they are also sites of contestation, resistance, transformation and negotiations Where Jhuma represents 'resisting' and 'deviant' body; Maina represents 'regulated', 'constrained' and 'disciplined' bodies. Patriarchy, under the excuse of 'norms' and 'cultural values' makes sure to discipline and control the 'overflowing' and 'dangerous' female sexuality. Further, when Jhuma was pregnant and ditched by her lover, she didn't bow down before the social and familial pressure rather she thought of leading a life of independence. The helplessness of her sisterin-law who treats her like a daughter could be seen significantly when she said, "What else can I do, Child? If her brother discovers this, he'll throw her out! When I look at her 
face, I do love her so. The tears slipped from Maina's eyes" (2008, p.75). And in return the patriarchy is seen in her brother's attitude who didn't take any initiative to find out his sister who left home, "Dhane answered her bluntly and then was silent: "if she is dead, we will hear of it. There's no need to search for her" (2008, p.87).

\section{Body as Space of Resistance}

But it is also true that women constantly show resistance through these geographical and bodily spaces. "Resistance in fact is a double edged sword in women's lives, one with which they constantly articulate and exhibit their struggle but one which does not always enable complete success. Resistance, nonetheless, remains central to their lives whether or not it achieves social transformation" (Thapan 15). Jhuma's audacious and unapologetic discourse and her choice of explicit sexual innuendos regarding her body and its desires itself hint towards her resisting against patriarchy 'resisting body' to a 'submissive body' who gives up to her misfortune at last and instead of choosing over her desire, she succumbs to suffocating patriarchy and drifts deep into the forest. Jhuma did not object and the pair of them walked away from the bazaar towards a nearby hollow" (p. 33).

\section{Conclusion}

The text Mountain Painted with Turmeric by Lil Bahadur Chettri shows how gender is socially constructed and how it 
is constituted through repetitive, performativity of body. There is nothing natural and certain dominating ideologies are passed on from generation to generation through certain cultural discourses. One needs to understand and questions this subtle, implicit, hidden ideology that has been disseminated to a larger group since ages legalizing and naturalizing certain ideas that empower a certain group by marginalizing certain other.

\section{References}

Foucault, M. (1980). Power/Knowledge: Selected Interviews and Other Writings, 1972-1977, Brighton: Harvester Press.

Hutt, Michael and Chettri, Lil Bahadur (2008) Mountains

Painted with Turmeric. New York: Columbia University Press.

Jameson, Fredric.(1991) Postmodernism, or, the cultural logic of late capitalism. duke University Press.

Lal, Malashri.(2000) The Law of the Threshold. IIAS: Shimla.

Lefebvre, Henri. (1991) The Production of Space. Trans.

Donald Nicholson-Smith. Oxford:

Blackwell Publishing.

Thapan, Meenakshi.(2009) Living the Body: Embodiment, Womanhood and Identity in Contemporary India. New Delhi: Sage Publications.

Raju, Saraswati,(Ed.). (2011) Gendered Geographies: Space and Place in South Asia, New Delhi. OUP, p.1. 
Rose, G. (1996),'As if the Mirrors Had Bled: Masculine Dwelling, Masculinist Theory and Feminist Masquerade', in Nancy Duncan (ed.), Bodyspace: Destabilizing Georaphies of Gender and Sexuality. London and Newyork: Routledge, pp 56-74.

Soja, E. W. (1996) Thirdspace: Journeys to Los Angeles and Other Real-and-Imagined Places, Oxford: Blackwell.

Dr. Tamishra Swain is an Assistant Professor at the Department of English and MEL, Banasthali University.

Ms. Shalini Shah is a Research Scholar at the Department of English and MEL, Banasthali University. 